University of Michigan Law School

University of Michigan Law School Scholarship Repository

Articles

Faculty Scholarship

5-1977

\title{
Judicial Protection of Minorities
}

Terrance Sandalow

University of Michigan Law School, sandalow@umich.edu

Follow this and additional works at: https://repository.law.umich.edu/articles

Part of the Civil Rights and Discrimination Commons, Constitutional Law Commons, Judges

Commons, Law and Race Commons, Law and Society Commons, and the Supreme Court of the United

States Commons

Recommended Citation

Sandalow, Terrance. "Judicial Protection of Minorities." Mich. L. Rev. 75 (1977): 1162-95.

This Essay is brought to you for free and open access by the Faculty Scholarship at University of Michigan Law School Scholarship Repository. It has been accepted for inclusion in Articles by an authorized administrator of University of Michigan Law School Scholarship Repository. For more information, please contact

mlaw.repository@umich.edu. 


\title{
JUDICIAL PROTECTION OF IMINORITIES
}

\author{
Terrance Sandalow*
}

In United States v. Carolene Products Co., ${ }^{1}$ Justice Stone suggested by indirection that there "may be narrower scope for operation of the presumption of constitutionality" when courts are called upon to determine the validity "of statutes directed at particular religious ... or national . . . or racial minorities."2 In such cases, he explained, "prejudice against discrete and insular minorities may be a special condition, which tends seriously to curtail the operation of those political processes ordinarily to be relied upon to protect minorities, and which may call for a correspondingly more searching judicial inquiry." Forty years later, that cautious suggestion has ripened into an attitude. The fact that legislation bears heavily upon the interests of a minority has come to be widely regarded as a reason for subjecting it to closer judicial scrutiny than other legislation whose constitutionality is challenged and perhaps as creating a presumption of its invalidity. Yet, exactly what is meant by these conclusions is, even now, far from certain. With the passing of time, moreover, the boundaries that circumscribed Stone's suggestion have become blurred. His reference to "discrete and insular minorities" has been read not merely as an elaboration of the reason for special judicial solicitude for "particular religious ... or national . . . or racial minorities," but as an open-ended invitation to extend similar protection to an ill-defined assortment of groups that have failed to attain their objectives through the political process.

To some extent, the uncertain contours of the notion that the judiciary bears special responsibility for protecting minorities from legislation injurious to them is a consequence of the continually changing composition of the Supreme Court in the years since Justice Stone wrote. The deeper reason for the uncertainty, however, is that it has never been clear precisely how the fact that legislation bears heavily upon a minority connects with the conclusion that it ought to be subjected to close judicial scrutiny. Except as frequency

* Professor of Law, The University of Michigan. A.B. 1954, J.D. 1957, University of Chicago.-Ed.

1. 304 U.S. 144 (1938).

2. 304 U.S. at 152 n.4.

3. 304 U.S. at 152 n.4. 
of repetition may have made it seem so, after all, the connection is not self-evident. "Democracy" means government by the people, either directly or through representation. Although a commitment to it does not entail acceptance of simplistic majoritarianism, there remains the question why, in a nation generally committed to democratic values, a minority should have a special claim to promote its interests outside the political process.

The belief that there are grounds for such a claim is the most frequent manifestation of an older and, very likely, still a more commonly held view, that judicial review is a necessary safeguard of the rights of minorities. Because of its stress upon rights-entitlements that are assumed to exist independently of the judicial process-the traditional view does not imply the degree of judicial activism that its more recent expression seeks to justify, but it is nonetheless father to it. What the latter owes to the former, specifically, is the belief that " 'holding democracy in judicial tutelage' is the only way that has yet been devised for preventing the 'tyranny of the majority' . . . from imposing on the minority."

My primary purpose in this essay is to explore these two versions of the argument that courts have a special responsibility for protecting minorities. Proponents of the argument often rely upon both versions indiscriminately. Yet, the two versions rest upon quite different premises concerning the nature of constitutional law and the judiciary's responsibility with respect to it. The more traditional version of the argument, that judicial review is a necessary safeguard of the rights of minorities, posits a conception of the judicial function that can be accommodated with the nation's commitment to democracy, but it can do so only by embracing a conception of constitutional law that is inconsistent with our national experience. The more recent version of the argument, stemming from Justice Stone's suggestion in Carolene Products, rests upon a more satisfactory conception of constitutional law, but this advance is achieved at the cost of adopting a conception of the judicial function that cannot be reconciled with democratic values.

In contending that neither version is satisfactory, I do not mean to suggest that courts have no part to play in protecting minorities against the hazards they face in the political process. My point, rather, is that conventional statements of the courts' role, in treating judges as the watchdogs of democracy, promise more than they can

4. P. Kurland, Politics, the Consttrution, and the Warren Court 182 (1970) (quoting J.S. MILL, ON LiberTY 68 (Everyman ed. 1910) ). 
justify. In the concluding section of this essay, therefore, I shall attempt to sketch an alternative conception of the courts' role, one that would permit them to protect minorities against the most serious threats to their interests and yet would respect the ultimate authority of representative institutions to determine the values to be expressed by law.

I.

The concern that democratic government will provide inadequate protection for minorities is as old as the nation-perhaps as old as the idea of democracy itself. The commonly expressed fear is that prejudice, the pressures or passions of the moment, or simply the prospect of gain may lead a majority to employ its power with insufficient respect for the interests of those who are in a minority. One possible safeguard against these dangers is to insulate certain interests thought to be fundamental from the hazards of the political process by adopting a constitution that includes provisions defining the limits of majority power. The rhetoric of Supreme Court opinions often employs just this conception of the Constitution. "The very purpose of a Bill of Rights," Mr. Justice Jackson once wrote in a classic formulation of the conception,

was to withdraw certain subjects from the vicissitudes of political controversy, to place them beyond the reach of majorities ..... One's right to life, liberty, and property, to free speech, a free press, freedom of worship and assembly, and other fundamental rights may not be submitted to vote; they depend on the outcome of no elections. ${ }^{5}$

Constitutions, however, are not self-enforcing. The same vices that may lead a majority to oppress a minority in the absence of a constitution may lead it to act in defiance of constitutional limits upon its authority. Earlier generations saw the threat primarily in terms of the hazard it posed for the security of property. More recently, concern has been directed toward threats to freedom of speech and other noneconomic rights. In either event, the underlying concern is the same, that a political majority cannot be trusted to respect rights that the Constitution affirms for all, majority and minority alike. $^{6}$

5. West Virginia State Bd. of Educ. v. Barnette, 319 U.S. 624, 638 (1943).

6. It is common to refer to "the rights of minorities" or "minority rights," but both phrases are misleading in suggesting that the rights referred to are uniquely those of minorities. The Constitution does not purport to protect the interests of minorities by conferring rights upon them alone. Its premise, rather, is that certain interests of individuals are to be immunized from governmental authority without re- 
Judicial review is often seen as a corrective for this supposed deficiency of democracy: since the Constitution is paramount law, judges can enforce the limitations that it imposes upon legislative authority. And since judges are trained in the traditions of the law and relatively insulated from popular pressures, they are more likely than legislatures to respect those limitations. Thus, it is said, judicial review poses no conflict with democracy. The conflict, if there is one, is with the antecedent decision to have a constitution that limits the power of the legislature. Judicial review is merely the instrument by which that decision is enforced.

The difficulty, of course, is that when the constitutionality of legislation is challenged the point at issue is not whether invalid legislation should be enforced, but whether the legislation is invalid. A dispute about the meaning of the Constitution is at the heart of the controversy. The defense of judicial review cannot, thus, rest simply upon the greater likelihood that courts will respect constitutional limitations. It must also come to terms with the question why courts, rather than legislatures, should have final authority to resolve controversies about the meaning of the Constitution.

The original answer to that question, that "[i]t is emphatically the province and duty of the judicial department to say what the law is," "7 is no longer satisfactory. It reflects a conception of constitutional interpretation that will not explain the evolving content of constitutional law. "[V]ery little of our constitutional law of individual rights," as Professor Thomas Grey has shown, "has any firm foundation in the model of judicial review which traces from Marbury $v$.

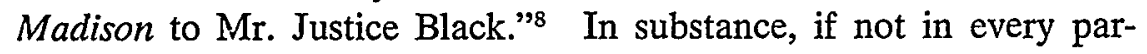
ticular, we have, in Grey's phrase, "an unwritten constitution." Its content is not fixed by the limits that the framers imposed upon the power of a majority. It depends, rather, upon evolving conceptions of the proper role of government in our society. ${ }^{9}$ The question today, accordingly, is not the same one that Chief Justice Marshall answered. The question that Marshall answered was whether courts or legislatures should have final authority to resolve controversies about the meaning of a document whose content was (understood to be) fixed at the time of its adoption. The question today is

gard to whether the individuals are members of the majority or of a minority. The frequent references to the rights so created as "minority rights" merely reflect a common understanding that minorities may have a greater need for such protection.

7. Marbury v. Madison, 5 U.S. (1 Cranch) 137, 177 (1803)."

8. Grey, Do We Have an Unwritten Constitution?, 27 Stan. L. REv. 703, 718 (1975).

9. See text at notes 30-34 infra. 
whether courts or legislatures should have final authority to resolve controversies about the meaning of a document whose content evolves over time.

If constitutional law is to change over time, the legislature's warrant for making the change is, prima facie, a good deal stronger than that of the courts. No doubt, it would be too facile simply to assert that it is the province and duty of the legislature to say what the law should be. Courts commonly exercise lawmaking responsibilities. But they do so, except when they speak in the name of the Constitution, subject to the revising authority of the legislature. The resulting distribution of authority between courts and the legislature, if not fully consistent with all interpretations of the democratic ideal, nonetheless respects its central premises: first, that law should be responsive to the interests and values of the citizenry, and, second, that in the long run it will be so only if lawmakers are amenable to popular control through ordinary political processes. A written constitution limiting legislative power may be seen as a tolerable compromise with that ideal in the service of other values. The possibility of reconciling the democratic ideal with constitutional limits upon legislative authority is considerably more problematic if the meaning of the Constitution and, therefore, the limits of legislative power vary over time according to the judgments of politically irresponsible judges concerning the rightful boundaries of the political process.

In an article published several years ago, Professor Ronald Dworkin argued that because controversies about the meaning of the Constitution involve disagreement between a majority and a minority, fairness requires that they be decided by the courts. ${ }^{10}$ In doing so, he explicitly rejected the contention that democratic values require the resolution of such controversies through the political process. To permit the legislature to decide the issues, as a representative of the majority, would, he maintained, violate a fundamental requirement of fairness, that one ought not to be a judge of his own cause. Dworkin thus appears to view the court's role to be like that of an umpire in a game and, interestingly, in a later article he explicitly invokes that analogy. ${ }^{11}$

The persuasiveness of Dworkin's argument depends upon how one views the task of determining the meaning of the Constitution, whether as one of discovery or one of creation. An examination of

10. Dworkin, The Jurisprudence of Richard Nixon, NEW YORK REVEW OF Books, May 4, 1972, at 27, 31-32.

11. Dworkin, Hard Cases, 88 Harv. L. Rev. 1057, 1078-82 (1975). 
his effort to analogize the courts' role to that of an umpire will help to clarify the point. An umpire, as Dworkin recognizes, exercises judgment, not choice. His task is to determine whether there has been compliance with the rules of the game, not what the rules ought to be. No one supposes that it would be proper for an umpire to legislate new rules as a game progresses, not even if he believed that its fairness or quality would be improved by the change. The question, then, is whether determining the validity of legislation is an activity, like that of an umpire, involving only the application of preexisting standards or whether it also involves legislating the rules by which constitutionality is determined. Dworkin conceives of the activity in the former way. He believes that rules of constitutional law exist that are sufficient to furnish an answer for every constitutional controversy. Discovering those rules may of course be very difficult, so difficult that, as he acknowledges in his most recent explication of the thesis, only Hercules, "a lawyer of superhuman skill, learning, patience, and acumen," would be capable of it. ${ }^{12}$ Nevertheless, they are there, and because they are fairness requires that those who claim their protection receive an impartial determination of that claim.

Since Dworkin writes in the latter part of the twentieth century, and not in the early years of the nineteenth, his claim that rules of constitutional law exist cannot rest upon as simple a foundation as Marshall's. In Marshall's time, it may have been adequate merely to inquire what a court was to do if a legislature passed a bill of attainder or ex post facto law, thereby treating the meaning of the relevant constitutional prohibitions as, if not self-evident, at least determinate. ${ }^{13}$ Two hundred years' experience under the Constitution has shown that the problem is more complex. If there is a correct answer to every constitutional question, as Dworkin claims, it nonetheless cannot be unchanging. The influence of altered circumstances and values has too frequently led to reinterpretation of the document to permit us now to accept a static theory of constitutional law. To establish the "fairness" justification for judicial review, accordingly, Dworkin must show that constitutional law can evolve by a process that does not require courts to choose among contending values.

I cannot within the confines of this essay adequately summarize Dworkin's extraordinarily complex argument in support of his position,

12. Id. at 1083.

13. Marbury v. Madison, 5 U.S. (1 Cranch) 137, 179 (1803). 
much less undertake a systematic critique of it. Much of the argument seems to me to provide a useful prescription for judges (or anyone else) called upon to interpret the Constitution. But I regard his claim that constitutional interpretation involves the discovery of existing rules, and not a choice among competing values, as little short of fanciful.

Dworkin's effort to maintain that position, while preserving the capacity of constitutional law to reflect changing circumstances and values, leads him to employ a strategy that, in one or another form, is common to all efforts to derive from the Constitution principles relevant to a world that could not have been anticipated when the document was adopted. He reads the language of the Constitution at a very high level of abstraction, in effect as a license to interpret its provisions as the embodiment of the evolving moral conceptions of successive generations. Thus, he writes, in deciding upon the constitutionality of the death penalty,

[i]t would be a mistake for the Court to be much influenced by the fact that when the [cruel and unusual punishment] clause was adopted capital punishment was standard and unquestioned. That would be decisive if the framers of the clause had meant to lay down a particular conception of cruelty . . . . But it is not decisive of the different question the Court now faces, which is this: can the Court, responding to the framers' appeal to the concept of cruelty, now defend a conception that excludes death? ${ }^{14}$

One might suppose that in deciding what is "cruel" (or "due process," "freedom of speech," etc.) a judge would be required to choose among competing values, thereby destroying the analogy between his task and that of an umpire. Dworkin argues, however, that a judge is not to decide such questions, he is to determine their answer. His task is to ascertain the principles that underlie the nation's moral judgments, as they have evolved through history. In making that determination, the relevant judgments are not those that would be revealed by a Gallup poll, but those that would result from the structure of principles that underlie the morality of the community.

Dworkin maintains that this process does not involve the exercise of discretion. It is, however, difficult to see how that can be so. As

14. Dworkin, supra note 10, at 28. Dworkin follows John Rawls in distinguishing between "concepts" and "conceptions:"

The difference is a difference not just in the detail of the instruction given but in the kind of instruction given. When I appeal to the concept of fairness I appeal to what fairness means, and I give my views on that issue no special stand-

ing. When I lay down a conception of fairness, I lay down what I mean by fairness, and my view is therefore the heart of the matter.

Id. (emphasis original). See also J. Rawls, A Theory of Justice 5-6 (1971). 
a matter of logic, the materials to which Dworkin would look in the effort to ascertain the community's morality ${ }^{\mathbf{1 5}}$ can be explained by an infinite number of principles, just as any number of points can be connected by an infinite number of curves. ${ }^{16}$ Although any human lawyer might find it impossible to discover a single principle which would suffice for that purpose, Hercules would discover an infinite number and would, therefore, confront the necessity of choosing from among them. Of course, on Dworkin's argument, Hercules would not be required, would not even be permitted, to make that choice if it had already been made by the community. But it is not obvious how even Hercules could know the community's choice. The only materials available to him would be those from which he is to draw the principles that underlie the community's morality. Once he commenced the effort, he would, being Hercules, see that there were an infinite number of possibilities. Even if he believed that the community had adopted only one, he would have no way of ascertaining it.

Dworkin's answer to the problem of how Hercules is to select from among alternative descriptions of the community's morality merely underscores the need for choice. Hercules must, Dworkin writes, approach the question before him not just as a problem of achieving a coherent account of community morality, but also as posing an issue of moral and political philosophy. ${ }^{17} \mathrm{He}$ is to select the "best" account of the community's morality. Competing philosophical traditions may, however, be expected to yield different conclusions about which account is best. Hercules cannot choose from among the traditions simply by determining which supports a coherent account of the community's morality since, by hypothesis, alternative coherent accounts are supported by different philosophical traditions. Unless Dworkin means merely to clothe in different garb a claim that natural law provides a controlling standard, a claim he neither avows nor defends, Hercules is ultimately left without a standard by which he can determine the validity of capital punishment. He must decide.

It is of course true, as Dworkin argues, that when Hercules decides he will not claim that his choice is best because he has

15. These appear to be the conventional materials of judicial decision (constitutional text, statutes, judicial precedent, etc.), subject to the interpretive techniques that are commonly employed in dealing with them. See Dworkin, supra note 11, at $1082-1101$.

16. See F. Cohen, Ethical Systems and Legal. Ideals 35 (1933); H. ReicheNBACH, EXPERIENCE AND PREDICTION 373-74 (1938).

17. Dworkin, supra note 11 , at 1084. 
chosen it, but that he has chosen it because it is best. ${ }^{18}$ In the absence of a controlling external standard, however, Hercules' claim that his choice is best has no apparent meaning other than that he thinks it is best. There is no reason to suppose that another judge with the same extraordinary capacities, say, Hercules fils, would not make a different choice. To be sure, Hercules père and fils would each feel constrained to decide as he has. In that sense, it might be said that neither is exercising discretion. But the existence of such subjective constraints is hardly to the point. What is crucial is that different judges, because of their different values, may be led to adopt different versions of the community's morality, each of which provides a fully coherent account of the judgments that they are bound to respect.

A lawyer who lacks Hercules' extraordinary capacities will, of course, not confront the same problems as Hercules, but he also will be unable to avoid the necessity of choice. His problem is likely to be that he cannot discover even a single principle that adequately accounts for all the judgments he is attempting to explain. Although he will be able to identify a number of candidates, none is likely to provide a perfect fit. In consequence, it will appear to him that the community's morality does not represent a coherent set of judgments. If he is to draw a principle from those judgments, accordingly, he will be required to conclude that some of them do not truly reflect the community's moral sense and, therefore, that he is entitled to ignore them. Deciding which judgments to ignore, however, requires choice. No doubt, the choice is constrained. A lawyer could not convincingly argue that, in a constitutional sense, imprisonment is "cruel," nor could he convincingly deny that maiming is. The contrary judgment is in each case too widely and deeply accepted. Judgments such as these are the starting points from which one begins in constructing principles. But there are also more doubtful judgments and, in deciding which is to be taken into account and which ignored, choice is inescapable.

The jurisprudence of the twentieth century has, therefore, not been wrong in concluding that law is not discovered, but constructed and that the rules judges apply do not exist independently of the process by which they are articulated. At times, Dworkin hinself comes close to recognizing this, as, for example, when he writes:

It does not follow from the fact that the man in the street disapproves of abortion, or supports legislation making it criminal, that he has

18. Id. at 1101-03. 
considered whether the concept of dignity presupposed by the Constitution, consistently applied, supports his political position. That is a sophisticated question requiring some dialectical skill, and though that skill may be displayed by the ordinary man when he selfconsciously defends his position, it is not to be taken for granted that his political preferences, expressed casually or in the ballot, have been subjected to that form of examination. ${ }^{19}$

Dworkin rightly stresses the importance of the dialectical process, but he nonetheless fails to give it its due. He sees that a judgment that would prohibit abortion is suspect if it has not emerged from such a process, but he fails to see that the structure of principles by which he would describe the community's morality must emerge from the same process. It is precisely because such a process does not underlie the community's moral judgments that a judge attempting to articulate principles that explain those judgments is engaged in a creative activity. The task in which he is engaged requires that he make choices that the community has not yet confronted. It is in that sense that the judge is necessarily a legislator.

The dialectical process, to put the point somewhat differently, is concerned with achieving consistency. A demonstration that a particular decision would be inconsistent with principles that are necessary to support decisions made at an earlier time, and to which there is a continuing sense of commitment, counts against the former. But it does not provide a decisive objection to that decision. Consistency may be achieved by abandoning the commitment to the earlier decisions. Suppose, for example, that a judge is called upon to determine whether capital punishment is "cruel" in a constitutional sense. Following Dworkin, the judge constructs a theory that "best" accounts for all prior judgments that he is bound to consider. Even if that theory is inconsistent with the imposition of capital punishment, a decision to invalidate a statute imposing such punishment would not simply be an expression of the community's moral principles. The judge has ascertained only that there is an inconsistency among the community's moral judgments. He cannot ascertain how the community would resolve the inconsistency for the simple reason that it has not done so. Confronted with the inconsistency, the community, acting through the political process, might abandon capital punishment. But it is also possible that it would, to the extent necessary, abandon the judgments from which the judge drew his account of the community's conception of cruelty.

19. Id. at 1107-08. 
Whether the judge sustains or invalidates capital punishment, accordingly, his decision cannot be justified as an effort to achieve correspondence with an existing societal morality. He is engaged in a creative, a legislative, activity, for in deciding he makes a choice that has not been made before. Nothing in Dworkin's theory tells us how that choice should be made. More important, for present purposes, nothing in Dworkin's theory tells us why that choice should be made by the judge and not through the political process. His claim is only that fairness requires an impartial determination if the appeal is to an existing standard that governs the situation. But even if that is so, the notion that constitutional law affords such a standard is chimerical.

Several years ago, a student in one of my classes attempted to defend the "fairness" justification for judicial review and the aptness of the umpire analogy by arguing that if rules were to be legislated during the course of a game, it would be preferable, because fairer, that the umpire do so rather than one of the players. This is a clever ploy, but it misses the central point. A game implies antecedent rules. Once it is understood that the constitutional law does not consist of rules embedded in the Constitution and that it cannot aim at correspondence with independently existing principles of societal morality, the utility of the game analogy and of notions of fairness drawn from it are at an end. Received ideas of fairness do not require an impartial decision when rules are to be legislated. To the contrary, although lack of a feasible alternative at times leads to the use of arbiters, other decisional processes, such as bargaining or voting, are more commonly employed in making such decisions. The question, then, is why such processes should be considered inappropriate in deciding the meaning to be given the Constitution.

\section{II.}

The idea that legislation directed against minorities should be subjected to close judicial scrutiny arises out of the breakdown of the belief that there are immanent rules of constitutional law. So long as judges are seen to be enforcing rules contained in the Constitution, there is no place for the notion that they owe differing degrees of deference to different kinds of legislation. Statutes either conform to those rules or they do not. And so, to recall Mr. Justice Roberts' familiar dictum, a court's only task when "an Act of Congress is appropriately challenged . . . as not conforming to the constitutional mandate" is "to lay the article of the Constitution which 
is invoked beside the statute which is challenged and to decide whether the latter squares with the former."20 Roberts understood, more than the frequently amused references to his dictum imply, that the task is not mechanical, but he wrote within a tradition that saw the task as calling for judgment, not choice. By the time Roberts wrote, however, that tradition was dying, a victim of several decades of sustained attack by legal realism.

The now-common perception that the rules enforced by courts are not contained in the Constitution poses a formidable challenge for the institution of judicial review. If constitutional rules are a product of judicial choice, the inevitable question is why, in a democracy, they should be permitted to control the decisions embodied in legislation. It is, after all, one thing to view the courts as enforcing a law of determinate content, a kind of social contract binding upon all because assented to by all, and quite another to view them as imposing their own conceptions of public policy upon governmental institutions that are more directly subject to popular control.

The realist critique thus dealt a devastating blow to the argument that judicial review is a necessary safeguard of the rights of minorities. The crucial premise of that argument is that the rights protected by courts were established in the Constitution. With the abandonment of the notion that the meaning of the Constitution inheres in the document, a radical transformation is required in the idea of a constitutional right. Constitutional rights can no longer be said to "exist," for their existence can only be determined post hoc: the "rights" of a minority are those of its interests that courts have accorded protection in the name of the Constitution. To define "rights" in this way, however, is to raise anew the question that the "minority rights" thesis is supposed to answer: why should a minority be able to look to a court for protection from legislative action? If rights are merely interests-interests that presumably must be weighed against other interests-why shouldn't the balance struck by the legislature be conclusive?

Justice Stone's answer to that question in Carolene Products was to direct attention to the quality of the process leading to the legislative decision. In general, as the decision in that case demonstrated, Stone believed that the task of striking a balance among competing interests is for legislatures and that courts ought to defer to their decisions. On occasion, however, a "special condition" might

20. United States v. Butler, 297 U.S. 1, 62 (1936). 
exist justifying distrust of "those political processes ordinarily to be relied upon . . . ." A "searching judicial inquiry" might, in such situations, serve as a corrective for the deficiencies of the political process. Justice Stone had earlier made a similar argument in discussing the judicial role when state legislation is challenged under the commerce clause. In South Carolina State Highway Department v. Barnwell Bros., Inc.,"1 decided little more than two months prior to Carolene Products, he had written for the Court that

when the regulation is of such a character that its burden falls principally upon those without the state, legislative action is not likely to be subjected to those political restraints which are normally exerted on legislation where it affects adversely some interests within the state. ${ }^{22}$

Justice Stone's reliance upon this passage to support his suggestion that "prejudice against discrete and insular minorities" might be a "special condition" warranting "searching judicial inquiry" of legislation directed against such minorities implied that the two situations are analogous.

There is, however, a crucial difference between legislation held to be invalid because unduly parochial and legislation held invalid because of its effect upon the interests of a minority. The vice of the former is that it is enacted by a legislature that is not politically responsible to all who are affected by it. A decision invalidating the legislation does not withdraw from the political process the question whether the objectives sought by proponents of the legislation are proper. It seeks, rather, to elicit an answer to that question from a more broadly representative legislature. The court thus acts not as a check upon democracy, but in its service. Precisely the opposite is true when legislation is invalidated because of its effect upon a minority. The court's action is not in the service of democracy, but a limitation upon it. The minority has not, typically, been excluded from the political process leading to enactment of the legislation. It has simply lost. What Justice Stone's suggestion fails to provide is a reason why, having lost, the minority should be entitled to review of the legislative decision in the courts.

Professor John Hart Ely has recently offered an interpretation of Justice Stone's thesis that suggests such a reason. ${ }^{23}$ When legisla-

21. 303 U.S. 177 (1938).

22. 303 U.S. at 184 n.2.

23. Ely, The Constitutionality of Reverse Racial Discrimination, $41 \mathrm{U}$. CHI. L. REv. 723 (1974). Although Ely is primarily intent upon demonstrating that courts are justified in treating as "suspect" any legislation directed against a racial minority, he is seemingly prepared to have the courts subject legislation to closer than normal 
tion singles out a minority for disadvantageous treatment, Ely argues, there is less basis than normally exists for confidence in the underlying assessment of costs and benefits by the legislature: since the costs of the legislation are not broadly distributed through the society, but are imposed only upon a minority, there is reason to fear that they have been undervalued. Hence, the balance of interests struck by the legislature is likely to be based upon a distorted assessment of the relative weight of the costs and benefits of the legislation. Stated this broadly, the argument would subject to close judicial scrutiny a substantial fraction of all legislation. Ely narrows the argument, however, and in so doing brings it closer to Justice Stone's concern for "discrete and insular minorities," by limiting it to situations in which the majority responsible for enacting the legislation consists of persons who have never been and expect never to be members of the affected minority.

Even with the gloss placed upon it by Professor Ely, Stone's suggestion is less persuasive than might be supposed from its broad acceptance. Neither Stone nor Ely contends that all legislation directed against a "discrete and insular minority" is invalid. Their claim is only that such legislation is "suspect." But if such legislation is sometimes valid and sometimes invalid, there must be standards by which a determination can be made. Yet, neither Stone nor Ely explicitly addresses the question how courts are to establish the legitimacy of the standards they employ to make the determination. It is, in other words, unclear exactly what it is that minorities are to be protected against. ${ }^{24}$

Justice Stone's dissenting opinion in Minersville School District v. Gobitis, ${ }^{25}$ the first case in which he acted upon the suggestion he had made in Carolene Products, offers a convenient illustration of the problem. In Gobitis, it will be recalled, the Court sustained the authority of a local school board to expel two students, members of Jehovah's Witnesses, who refused to participate in a daily flag salute ceremony. Stone's dissent was devoted primarily to defining the in-

scrutiny whenever any minority is singled out for disadvantageous treatment. $\mathrm{He}$ does, however, suggest a number of theories for narrowing the argument he advances. Id. at 734 n.45. None of the refinements affect the discussion in the text.

24. It is, moreover, unclear just who it is that is to be protected. Justice Stone seems to have had in mind only racial, national, or religious minorities. But the reason he advanced for granting special protection to these groups, that the political process might not adequately protect "discrete and insular minorities," is potentially applicable to other groups as well. Yet, without further specification of the defects in the political process that call for "searching judicial inquiry," it is hard to know which groups should be the beneficiaries of this special judicial solicitude.

25. 310 U.S. 586 (1940), overruled in West Virginia State Bd. of Educ. v. Barnette, 319 U.S. 624 (1943). 
dividual and governmental interests at stake in the controversy and to an argument that the former outweighed the latter. For Stone to have rested only upon that argument, however, would have left his position vulnerable to the counter-argument made by Justice Frankfurter on behalf of the Court, that "so long as the remedial channels of the democratic process remain open and unobstructed," the task of balancing competing interests is political, not judicial. ${ }^{20}$ Stone's answer to Frankfurter was to invoke Carolene Products. After paraphrasing the suggestion that courts have a special role in protecting "discrete and insular minorities," he wrote:

Here we have . . a a small minority entertaining in good faith a religious belief, which is such a departure from the usual course of human conduct, that most persons are disposed to regard it with little toleration or concern. In such circumstances careful scrutiny of legislative efforts . . . is especially needful if civil rights are to receive any protection. Tested by this standard, I am not prepared to say that the rights of this small and helpless minority . . . is to be overborne by the interest of the state. ${ }^{27}$

If the references to "civil rights" and the "rights of this small and helpless minority" are to be understood to mean, as Chief Justice Marshall and Professor Dworkin would have it, that the Constitution establishes certain limits upon governmental authority, the fact that the compulsory flag salute burdened only a minority adds nothing to the argument. Immunity from that burden either is or is not one of the rights established by the Constitution. To be sure, the fact that the burden fell only upon a minority provided the occasion for judicial review-if the burden had fallen with equal weight upon the majority, presumably it would not have been enacted-but there is no apparent reason why it should enter into the argument about whether the right exists. In principle, the right and judicial role in enforcing it should be the same even if a majority of the population were burdened.

Justice Stone's insistence upon the need for "careful [judicial] scrutiny" because a "small and helpless minority" was distinctively burdened thus seems to presuppose that the Constitution does not itself enact the immunity claimed in Gobitis. The underlying notion appears to be that the Court is to decide whether there should be an immunity by balancing the competing interests of the state and the affected individuals. But if the immunity is not enacted by the Constitution, how is the Court to establish the legitimacy of a conclu-

26. 310 U.S. at 599.

27. 310 U.S. at 606 (Stone, J., dissenting). 
sion that a compulsory flag salute imposes an impermissible burden upon objecting students? The call for "careful scrutiny" obscures the fact that when scrutiny ends there remains the need for a decision-and hence the necessity of justifying the decision.

Now a decision can be justified in only two ways, either by demonstrating that it conforms to a controlling standard or that it is the result of a process that is appropriate for making such decisions. Courts traditionally have attempted to justify constitutional decisions in the former way. Justice Stone's emphasis on the deficiencies of the legislative process looks toward the second type of justification: courts can legitimately substitute their judgments for those of legislatures, at least when they are determining the validity of legislation directed against minorities, because the judicial process is more appropriate than the legislative for making the choices that are required in that setting.

It is hard to see how, in its pure form, such a position can be defended-and, to my knowledge, no student of constitutional law has seriously attempted to do so. ${ }^{28}$ Prevailing ideas of fairness, as suggested above, do not call for impartial decisions when rules are to be legislated. To the contrary, processes of decision that permit participation by those affected are generally regarded as more appropriate for that purpose. No one supposes, for example, that fairness requires courts to substitute their judgments for those of legislatures with respect to tax rates for the wealthy, the level of welfare payments for the poor, or the content of regulations imposed upon milk producers in the interest of consumers. Such issues, it is commonly understood, are to be resolved through the political process, and that is so even though there is a risk that the majority will not fully appreciate the costs that are imposed upon the minority. Yet, if the argument for an active judicial role in protecting minorities rests simply upon a claim that fairness requires impartial decisions to settle conflicts between a majority and a minority, these cases do not differ from those in which courts are now generally held to be entitled to substitute their judgments for those of legislatures.

Nor is it obvious that other arguments might be marshaled to support a contention that standards fashioned by the judiciary to settle conflicts between a majority and a minority are justified merely because of the process from which they have emerged. As a nation, we are committed to the idea that government, to be ethically de-

28. Though perhaps Judge J. Skelly Wright came close in Hobson v. Hansen, 269 F. Supp. 401, 506-08 (D.D.C. 1967), affd. as modified sub nom. Smuck v. Hobson, 408 F.2d 175 (D.C. Cir. 1969). 
fensible, requires the consent of the governed. The notion that the requisite consent might be found in an ancestral assent to be governed by institutions that lack continuing responsibility to the citizenry was rejected long ago. Since pre-Revolutionary times, the active and continuous participation of the governed in their government, either directly or by representation, government "of" and "by" the people, has been understood to be central to the democratic ideal. Courts not only are unable to draw upon this source of legitimacy, but in setting their judgment against that of the legislature, they oppose the very agency of government that is most clearly entitled to do so.

Since judicial decisions protecting minorities cannot be justified solely by reference to the process from which they emerge, their justification must depend upon a demonstration that they conform to a controlling standard. Yet, the courts' inability to make such a demonstration is what led Justice Stone to seek a justification for the Court's constitutional role in the deficiencies of the legislative process. If neither justification is available, how are judgments of the kind required by Carolene Products to be defended?

For some years now, the conventional answer to that question has drawn upon weaker versions of both justifications. The heart of the argument is a claim that the Constitution should not be read as prescribing rules, but as committing the nation to certain values. Such a reading is said to be appropriate because the Constitution was "intended to endure for ages to come, and, consequently, to be adapted to the various crises of human affairs.". Its provisions must, accordingly, be read with sufficient breadth to accommodate changing circumstances and the heightened understanding of successive generations regarding the requirements for achieving the goals that it establishes. Ultimate responsibility for this accommodation, the argument continues, is better entrusted to courts than to legislatures. Their relative isolation from men and events and their commitment to the processes of reason helps free them from momentary pressures and passions and permits them to take a longer view, thereby increasing the prospects that due recognition will be given to the values contained in the Constitution.

It is worth noting that nothing in the argument thus far suggests a more active role for courts in reviewing legislation directed against minorities than in reviewing any other legislation. Courts are simply

29. McCulloch v. Maryland, 17 U.S. (4 Wheat.) 316, 415 (1819) (emphasis original). 
held to have general responsibility for determining whether legislation is adequately respectful of constitutional values. The notion that in discharging that responsibility courts sometimes owe deference to legislative judgments and that they owe less deference to legislation directed against minorities than to legislation generally depends upon a number of additional considerations. If the Constitution is read as embodying broad values, not detailed prescriptions, the decision whether legislation is valid will, of necessity, frequently depend upon an appraisal of complex factual issues and subsidiary value choices not specified in the Constitution, both of which are within the province of the legislature. Since the areas of judicial and legislative competence are not neatly separable, there is an everpresent risk that courts will either encroach upon the legislature's prerogatives or fail to discharge their responsibility for the protection of constitutional values. Justice Stone's suggestion in Carolene Products may be seen as an effort to escape from this dilemma. Courts may safely defer to the judgments underlying legislation that touches upon constitutionally protected interests if the burden of the legislation is broadly distributed through the population. In such circumstances, a fair evaluation of those interests is likely to be achieved through the political process, and judicial review is necessary only for the aberrant cases in which the disregard of constitutional values is clear. But the political process offers no such assurance of a fair evaluation of constitutionally protected interests when only the interests of a minority are adversely affected. Hence, the need for close judicial scrutiny.

The persuasiveness of this argument depends upon how close a relationship exists between the values that receive expression in contemporary constitutional law and those that were written into the Constitution by the framers. The closer that relationship the more persuasive the claim that judicial review serves primarily to assure adequate respect for the latter. Conversely, as the relationship diminishes, the claim becomes more tenuous, and the more courts must be seen as subjecting the political process to limits whose legitimacy has yet to be established.

From this perspective, the fatal weakness of the argument is its facile assumption that the values expressed in contemporary constitutional law are those written into the Constitution by the framers. At nearly every crucial point, and especially in those areas of constitutional law concerned with protecting minorities, the values of the present, not those of the past, play a dominant role in determining the content of constitutional doctrine. During the past two decades, 
the equal protection clause has served as the main vehicle for judicial protection of minorities. The decisions that limit legislative power in reliance upon that clause necessarily depend, as I have argued elsewhere, upon value premises that cannot be derived from the text or the intentions of those responsible for its adoption. ${ }^{30}$ Apart from its immediate historical purpose of assuring blacks equality with whites in respect of (what were understood to be) the necessary incidents of freedom, ${ }^{31}$ the clause can fairly be read only as proscribing unreasonable classifications. The crucial judgment is whether a classification is unreasonable, and that judgment, as the subsequent history of the clause demonstrates, depends upon the values of a later day. Thus, a Supreme Court committed to the values of a laissezfaire economy found a good deal of "irrationality" in governmental regulation of the economy. With the passing of that commitment, reasons were found to support classifications that would once have been considered unreasonable. Today, similarly, when the equal protection clause is employed to protect aliens, illegitimates, and indigent defendants, the underlying values that are expressed are not those of the Reconstruction Congress but of the present.

The influence of contemporary values is no less dominant in shaping the constitutional doctrines that have evolved under relatively more specific provisions of the Constitution, provisions such as those guaranteeing "the freedom of speech [and] of the press" and the right of a criminal defendant "to have the assistance of counsel for his defense." Of course, the values of the present are not wholly unrelated to those of the past. One may find in contemporary constitutional doctrine echoes of the concerns expressed by the framers in the limits that they imposed upon government. But they are only echoes, and often very distant ones. The contrary claim, that the values written into those provisions significantly inform contemporary constitutional judgment, depends upon abstracting those values from the particular limits that the framers meant to impose upon government. Abstracting the values from their historical context, however, inevitably leads to their distortion. Values do not exist in the abstract; they are forged in response to particular circumstances and in the collision of multiple purposes that impose bounds upon one another. Wrenching the framers' values, their "larger purposes," from the particular limits they meant to impose upon government leads to a loss of perspective, a perspective that might better

30. Sandalow, Racial Preferences in Higher Education: Political Responsibility and the Judicial Role, 42 U. CHI. L. REv. 653, 654-57 (1975).

31. See id. at 664-66. 
enable courts to see that those limitations were not imperfect expressions of a larger purpose but a particular accommodation of competing purposes. In freeing themselves from those judgments, courts are not serving larger ends determined by the framers but are making room for the introduction of contemporary values. Thus, decisions such as Johnson v. Zerbst, ${ }^{32}$ New York Times Co. v. Sulli$v a n,{ }^{33}$ and those extending constitutional protection to sexually explicit materials, ${ }^{34}$ decisions that are at the core of contemporary constitutional tradition, are not in any significant sense derived from the Constitution, viewed as an historical document. The justification for them, as for the great bulk of our constitutional law of individual rights, depends rather upon an evolving constitutional tradition that owes far more to the values of the twentieth century than to those of the late eighteenth.

If the values expressed in constitutional law are not derived from the Constitution but, as the late Alexander Bickel once wrote, from "the evolving morality of our tradition,"35 it is not apparent what courts are to look for when they subject legislation directed against minorities to close scrutiny. Precisely because that tradition is evolving, it cannot afford the courts a scale for determining whether the values it embraces have been given due weight by the legislature. The notion that certain types of legislation should be subjected to close scrutiny assumes, in other words, a degree of fixity in constitutional values. But if the values expressed by constitutional law change over time, by what standard are courts to determine whether a particular step in the evolutionary process is or is not permissible?

To put the point more concretely, suppose that after full debate Congress were now to enact a compulsory flag salute similar to that involved in Gobitis. How is a court, upon complaint of an objecting student, to decide whether Congress has given due weight to the first amendment values invoked by the student? Ultimately, that decision must turn upon the answers to a series of interconnected empirical and value questions that Congress seems more competent to answer than a court."3; But assuming for the moment that the congressional

32. 304 U.S. 458 (1938).

33. 376 U.S. 255 (1964).

34. See W. LockhaRT, Y. KaMisar, \& J. Choper, Constitutional LAW 979-1039 (4th ed. 1975).

35. A. Bickel, The Least Dangerous Branch 236 (1962).

36. For example, are the fostering of patriotism and a sense of national identity appropriate objectives of the public schools; do flag salute ceremonies serve those objectives; would the effectiveness of the ceremonies, for the mass of children, be diminished if some children were excused; how heavy a burden do such ceremonies impose 
judgment is to be considered suspect because of a fear that the political process does not properly value the interests of minorities, there remains the question how the court is to decide the crucial value questions, whether the congressional objectives are permissible and, if so, whether they outweigh the burden imposed upon dissenting students. No one supposes that the judges are entitled to employ their personal values in fashioning an answer to those questions. Yet, if they are to look to an evolving social morality, what surer evidence can there be of its present state than congressional enactment of the legislation after full debate?

A court might, of course, seek to demonstrate that the challenged legislation is in some sense an aberration, that it does not truly reflect the enduring values of the society. At its best, such an effort would take the form urged by Professor Dworkin, an attempt to demonstrate that a compulsory flag salute is inconsistent with the values reflected in other judgments broadly accepted in the society, judgments embodied in legislation, court decisions, and the expected response to hypothetical cases. But even if the demonstration were successful, the court would, as argued above, have succeeded in showing only the existence of an inconsistency, not how the inconsistency should be resolved. It could not determine that Congress had failed to give due weight to first amendment values because the tradition that determines the weight those values are to be given is an evolving one. If the court is to judge from within an evolving tradition, in other words, it lacks the fixed point of reference that is necessary for deciding whether first amendment values were given their due. And if it attempts to define a fixed point of reference outside the tradition, it confronts an inability to justify its standard.

The awareness of this dilemma has contributed to the courts' increasing reliance upon the equal protection clause, especially to protect minorities. In contrast with decisions under "substantive" provisions such as the first amendment or the due process clause, decisions that rest upon the equal protection clause may appear to leave questions concerning the proper limits of the political process to legislative resolution, permitting courts to provide significant protection for the interests of minorities without arrogating to themselves power to make value choices they cannot justify. As Mr. Justice Jackson wrote in the classic statement of the argument:

upon children who, for religious or other reasons, object to participating in them; are there alternative means by which the congressional objectives might be achieved that would be less burdensome to objecting students; what would be the costs of such alternatives; and so on. 
Invocation of the equal protection clause . . . does not disable any governmental body from dealing with the subject at hand. It merely means that the prohibition or regulation must have a broader impact. . . . The framers of the Constitution knew, and we should not forget today, that there is no more effective practical guaranty against arbitrary and unreasonable government than to require that the principles of law which officials would impose upon a minority must be imposed generally. Conversely, nothing opens the door to arbitrary action so effectively as to allow those officials to pick and choose only a few to whom they will apply legislation and thus to escape the political retribution that might be visited upon them if larger numbers were affected. ${ }^{3 i}$

The difficulty, of course, is that legislatures do not act irrationally. A legislative decision to treat a minority differently from the majority always rests upon some policy. Deciding whether that policy warrants distinctive treatment of the minority requires value choices no less difficult for courts to justify than those that equal protection analysis in theory permits them to avoid, choices that may indeed, because of the absence of any textual support for them, be more difficult to justify than those required under relatively more specific provisions.

III.

As the preceding pages demonstrate, the task of defining and justifying the role that courts may legitimately play in protecting minorities must be accomplished within a larger framework of ideas concerning the appropriate sources of constitutional judgment and the proper limits of judicial authority in a democracy. Constructing such a framework is not a suitable undertaking for a brief essay. Nevertheless, since $I$ believe that courts do have an important and a legitimate part to play in protecting minorities against the ordinary workings of the political process, it would be inappropriate to conclude without suggesting the grounds for that judgment. Very briefly, therefore, I want to sketch the outlines of an argument that would afford minorities judicial protection against the most serious risks they face in the political process and yet, by respecting the ultimate authority of the political process to determine the values to be expressed by law, meet the criticism that in protecting minorities courts are acting inconsistently with democratic values.

The central problem that courts confront in erecting constitutional protections for minorities is no different from that which they

37. Railway Express Agency, Inc. v. New York, 336 U.S. 106, 112-13 (1949) (Jackson, J., concurring). 
face in dealing with other constitutional problems, an inability to justify the standards they employ to limit the permissible outcomes of the political process. The source of that problem, I want to suggest, is the failure of doctrines defining the judicial role in constitutional adjudication to come fully to terms with a fundamental change that has occurred over the past several decades in the way that constitutional law is conceived. Prevailing doctrines defining that role are still, in large measure, the product of a time when the rules of constitutional law were understood to be embedded in or at least derivable from the Constitution. Partly as a result of substantive changes in constitutional law, but even more as a consequence of changing ideas about the nature of law, that conception of constitutional law is no longer persuasive. To account satisfactorily for its content and the functions it performs, constitutional law must now be understood as the means by which effect is given to those ideas that from time to time are held to be fundamental in defining the limits and distribution of governmental power in our society. So profound a change in the sources of constitutional judgment requires the reexamination of doctrines defining the judicial role in constitutional adjudication. Of course, that reexamination has to some extent occurred and, as suggested above, it has led to some changes in the way that the courts' role is generally understood. ${ }^{38}$ Nevertheless, there remain doctrines that developed corollary to the earlier conception of constitutional law that have uncritically been given continued effect.

Thus, traditional constitutional analysis generally regards the decisionmaking process that precedes governmental action as irrelevant to the action's validity. ${ }^{39}$ This indifference to process is manifested, first, by a failure to take into account where in the hierarchy of government an allegedly invalid decision was made. Illustratively, West Virginia State Board of Education v. Barnette, ${ }^{40}$ which overruled Gobitis, is conventionally understood as establishing the invalidity of compulsory flag salute ceremonies in public schools without regard to whether the requirement is adopted by an administrative agency, as occurred in that case, or by a school board, a state legislature, or the Congress. The lack of concern for process is revealed also by the courts' frequent failure to consider whether enactment of allegedly invalid legislation was preceded by legislative

38. See text at notes 21-23 supra.

39. The obvious exceptions are those situations in which the Constitution is read to guarantee or prohibit a particular decisionmaking process, as for example the guaranty of a jury trial or the prohibition of bills of attainder.

40. 319 U.S. 624 (1943). 
consideration of the controlling issues. For example, in United States v. O'Brien, ${ }^{41}$ the Supreme Court, effectively deferring to Congress by failing to canvass the need for such legislation, sustained a statute prohibiting "draft card burning" even though the Congress had given no attention to any of the issues upon which the statute's constitutionality depended and had failed even to recognize the possibility that the prohibited conduct was a form of speech arguably entitled to constitutional protection. ${ }^{42}$ As a result, legislation that concededly impinged upon first amendment values was given effect without a deliberate judgment by either Congress or the Court that the encroachment was justified.

Judicial indifference to the decisionmaking process underlying challenged governmental action follows naturally from a model of constitutional adjudication that assumes rules of constitutional law are embedded in or can be derived from the Constitution. Since those rules are assumed to have an existence independent of the process by which they are announced, there is no reason why the decisionmaking process that precedes governmental action should influence a judgment about its consistency with the rules. The action is either consistent with the rules or it is not.

But the same is not true when constitutional law is understood as the expression of evolving societal norms. A court cannot lay a challenged statute beside a societal norm and decide whether the former squares with the latter. Societal norms are not a "brooding omnipresence" merely awaiting discovery by a sufficiently keen observer. They must be constructed and, inevitably, their construction must be effected through some process. ${ }^{43}$ A judgment whether governmental action is consistent with societal norms is, for that reason, closely bound up with judgments about the process through which the norms should be constructed. In deciding whether governmental action does conform to societal norms, accordingly, a court must consider whether, by reason of the decisionmaking process leading to it, the action ought to be understood as establishing those norms.

The central problem in devising a satisfactory theory of judicial review is, thus, to define and justify the process by which societal norms should be constructed for the purpose of giving content to constitutional law. Familiar arguments persuasively support the partici-

41. 391 U.S. 367 (1968).

42. See Alfange, Free Speech and Symbalic Conduct: The Draft-Card Burning Case, 1968 Sup. CT. Rev. 1, 3-6.

43. See text at notes 14-19 supra. 
pation of courts in that process. ${ }^{44}$ Just as every "intuitive twitch" is not to be taken as expressing the values of an individual, not every action of government is to be understood as expressing the values of the society. ${ }^{45}$ Deciding whether one or another action is consistent with our values requires reflection. Judicial review, in Justice Stone's familiar phrase, offers the opportunity for a "sober second thought," 46 an occasion for considering whether challenged governmental action is consistent with broadly shared societal values. By subjecting such action to the test of principle-a test of conformity with principles that are themselves subject to being tested by the results that they imply-courts can increase the prospects that governmental action will conform to those values. Of course, courts are not the only institutions of government capable of testing action against principle, but experience suggests that because of their practices and their place in the governmental system they are more likely than others to do so.

These arguments, however, demonstrate only that courts have a part to play in the process of deciding whether governmental action conforms to societal values, not that their decisions should be final. Since societal values cannot be directly apprehended, the principles that courts employ to test governmental action must be understood as expressing not the values of society as such but a particular construction of those values. No doubt, that construction will often correspond to a consensus within the society. Thus, as I suggested earlier, no one can doubt that, within the traditions of our society, maiming is cruel and imprisonment is not. Our confidence in that judgment rests in part upon the certainty that a broadly representative political process would not, after deliberation, reach a decision inconsistent with it. When courts are called upon to consider the validity of legislation, however, the source of that confidence is obviously no longer present. The question then is whether a court's construction of those values should prevail over the decision of the legislature.

If constitutional law is to be understood as expressing contemporary societal norms, it is hard to see how courts can, in the end, set their judgment concerning the content of those norms against a deliberate and broadly based political decision, say, one made by

44. See, e.g., A. Bickel, supra note 35, at 24-27.

45. The phrase is Thomas Grey's. Grey, The First Virtue, 25 STAN. L. Rev. 286, 300 (1972). (1936).

46. Stone, The Common Law in the United States, 40 Harv. L. Rev. 4, 25 
Congress after full debate or embodied in legislation recently enacted by most states. Political decisions such as these ought to be considered controlling not because they evidence societal normswere they only evidence they would, presumably, be subject to refutation by other evidence-but because the process that has led to them is the ultimate source of law's legitimacy in a democratic society. That process confers legitimacy upon the decision not merely because it registers consent in some abstract way but, as I have urged elsewhere, because

political responsibility is crucial to the democratic ideal that governmental policies ought to respond to the wishes of the citizenry. . . . First, it provides a means by which government is made more sensitive to the impact of a policy upon the various segments of the society and thereby contributes to the calculation of gains and losses resulting from that policy. Second, since an appraisal of the consequences of policy involves not merely a measurement of gains and losses, but a judgment of what is to count as a gain or loss and how these shall be balanced, political responsibility helps ensure that governmental policy will not depart too far from the values of citizenry. Finally, the political responsibility of the legislature creates an incentive for compromise and accommodation that facilitates developments of policies that maximize the satisfaction of constituents' desires. ${ }^{47}$

A consensus achieved through a broadly representative political process is, thus, as close as we are likely to get to the statement of a norm that can be said to reflect the values of the society.

Most governmental action that is subject to constitutional challenge is not, however, the product of a process that can reasonably be understood as establishing societal norms. Often the decisions that underlie such action have been taken by administrative bodies that lack direct political responsibility. Even when political responsibility is more direct, the limited functional responsibilities of, say, a school board or the limited constituency of a city council or even a state legislature preclude a claim that their decisions can be taken as establishing societal norms. Such bodies of course have important decisionmaking responsibilities, but it is generally understood that those responsibilities are to be performed within the framework of norms that the larger society regards as fundamental. Judicial review of their decisions may thus be seen as a means of increasing the prospects that the actions of politically subordinate governmental institutions respect broadly shared national values. The purpose of such review is not to check democracy, but to promote it by ensuring that the evolution of such values occurs through an appropriate process.

47. Sandalow, supra note 30 , at 695 . 
Many decisions of Congress, similarly, cannot reasonably be understood as establishing societal norms. Frequently, the issues that underlie a constitutional challenge to legislation have not been noticed in the course of its enactment, perhaps because they were overlooked, perhaps because the issues have become apparent only in particular applications of the legislation that were not clearly anticipated. Even when such issues have been noticed, they may have received only cursory examination, and then only in committee, for the attention of the Congress may have been directed at other features of the legislation or, as must often occur, the legislation itself may have generated insufficient interest to elicit the full attention of Congress. Inability to consider carefully many of the constitutional issues raised by legislation is the product of conditions and practices deeply embedded in Congress' structure and processes, including the size of its workload, the division of labor that the workload requires, and, when legislation has only regional significance, the tendency to defer to the judgment of those legislators whose constituencies are most immediately affected. The effect of such conditions and practices upon the ordinary operations of Congress not only suggests that the mere enactment of legislation should not be understood as an authoritative statement of societal norms, but also that there is need for an institution to examine the question whether legislation that has not received full attention of Congress respects values that within our tradition may reasonably be regarded as fundamental.

I am not suggesting that legislation should be held unconstitutional merely because it has failed to receive full-scale consideration by Congress. My point, rather, is that if governmental action trenches upon values that may reasonably be regarded as fundamental, that action should be the product of a deliberate and broadly based political judgment. The stronger the argument that governmental action does encroach upon such values, the greater the need to assure that it is the product of a process that is entitled to speak for the society. Legislation that has failed to engage the attention of Congress, like the decisions of subordinate governmental institutions, does not meet that test, for it is likely to be the product of partial political pressures that are not broadly reflective of the society as a whole. In subjecting such legislation to constitutional review, courts do not stand sentry over democracy. They serve, rather, as its agent, an institution whose purpose is to help ensure that the effective delegations of power required in a complex society do not 
lead to governmental action that departs from the society's fundamental values.

If judicial review is to be understood in this way, however, courts must be prepared to yield to political decisions that do reflect the deliberate judgment of representative institutions which, just because they are representative, can speak for the society more authoritatively than can courts. Once an historical standard of constitutional interpretation has been abandoned, a bridge that in the United States was crossed long ago, there is no higher standard to which courts can appeal. It follows that Gobitis and Barnette should be understood as presenting a quite different problem from that posed in the hypothetical case stated above, in which Congress after full debate has required public school students to participate in flag salute ceremonies. Neither the school board in Gobitis nor the administrative agency in Barnette can plausibly be understood to speak with the same authority as the Congress in representing the views of the nation. If, therefore, constitutional law is to be understood as expressing evolving social norms, it seems entirely appropriate that the Supreme Court might hold, as it did in Barnette, that a compulsory flag salute ceremony adopted by an administrative agency is an impermissible burden upon religious freedom and yet sustain precisely the same requirement if it were to be subsequently enacted by Congress.

Judicial determinations of unconstitutionality would on this analysis become suspensive vetoes; their effect would be similar to that currently given to decisions invalidating state legislation under the commerce clause. Instead of exercising a power that they can no longer justify, that of determining the limits of the political process, courts would, as they now do under the commerce clause, concern themselves with ensuring that governmental decisions which touch upon interests that our society regards as fundamental are made through an appropriate process. Giving judicial decisions the effect of suspensive vetoes would not, as critics of the thesis may wish to suggest, confer upon Congress a power to amend the Constitution, any more than conventional analysis authorizes courts to amend the Constitution when it recognizes the propriety of their reinterpreting the document's provisions in the light of evolving social values. It would merely recognize that if constitutional law is to evolve over time, the legitimacy of the changes depends upon popular consent expressed through a democratic political process and that, once the meaning of the Constitution is loosed from its historical moorings, 
there is no standard to which a court can repair for the purpose of imposing limits on that process.

The belief that judicial review is a necessary bulwark against the excesses of democracy will lead some readers to conclude that acceptance of the argument sketched in the preceding paragraphs would deprive minorities of the most important safeguard of their interests. I cannot in a brief essay lay such fears completely to rest, but perhaps enough may be said to indicate that they are greatly exaggerated. The argument that I have advanced calls for judicial submission only to decisions that have been deliberately made by Congress and, perhaps also, to decisions expressed in legislation adopted by most states. In assessing the impact of that suggestion upon minorities, it is important to understand that the political process leading to such decisions contains prodigious internal safeguards for their interests.

Foremost among these is the effect upon the political process of the extraordinary variety of interest groups in the United States and the crosscutting loyalties and identifications that exist among the members of such groups. As long ago as the 10th Federalist, perhaps still the most important contribution by an American to political theory, Madison pointed out the importance of diversity in guarding against the "tyranny of the Majority":

Extend the sphere [of democratic government] and you take in a greater variety of parties and interests; and you make it less probable that a majority of the whole will have a common motive to invade the rights of other citizens; or if such a common motive exists, it will be more difficult for all who feel it to discover their own strength, and to act in unison with each other. ${ }^{48}$

Read as a prediction, Madison's argument has proved to be remarkably prescient, though perhaps in ways that he did not fully foresee. Political parties have arisen as the "mobilizer of majorities," and it is through them that "the will of the majority" is expressed. But, as Carl Auerbach has written:

To mobilize a majority of the votes in an election, each political party must appeal to a variety of "interests" and a wide spectrum of opinion. As a consequence of their catholicity, the major parties are unthinkable as instruments of tyranny because "it is impossible for the party in power to oppress any element of the opposition party without oppressing a corresponding element within its own ranks."

48. The Federalist No. 10, at 61 (Mod. Lib. ed. 1937) (J. Madison). 
In addition, the party in power knows that any effort to "tyrannize" a particular minority may also antagonize other groups in the majority coalition, as well as the "independents" pursued by both major parties, and, therefore, may cost it the next election.

In short, the "monolithic" majority . . . does not exist; the majority is but a coalition of minorities which must act in a moderate, broadly representative fashion to preserve itself. ${ }^{49}$

Whether or not one is prepared to go as far as Sidney Hook in proclaiming that "the dictatorship of the majority' [is a] bugaboo which haunts the books of political theorists but has never been found in the flesh in modern history," ${ }^{50}$ it seems plain that pluralistic politics furnish substantial safeguards to minorities in those situations in which I have urged that courts must yield to legislative judgment. For it is in just those situations that the visibility of governmental decisions permits minorities to draw upon the full range of protections that pluralism offers.

In recent years, the idea that pluralism serves an an effective safeguard of minority interests has come under increasing attack. Thus, Judge J. Skelly Wright, in a spirited defense of the Warren Court's decisions, has written that "[t]he big winners in the pluralistic system are the highly organized, wealthy, and motivated groups skilled in the art of insider politics. They have resources to trade for other benefits, and the resources that it takes to press their claims successfully." 51 But, he goes on to argue, "unorganized, poor, unskilled minorities" who lack these resources do not obtain similar advantages: their interests are not the ones that "the pluralistic system regularly rewards." 52 Thus, he concludes, courts must take an active role in defending those interests.

The question of how well "unorganized, poor, unskilled minorities" fare in pluralistic politics is, however, more complex than Judge Wright's comments suggest, and it calls for a correspondingly more refined analysis of the courts' role than he advances. Initially, there is a need to distinguish, as he does not, between the ability of minorities to obtain the enactment of legislation they desire and their ability to block legislation they oppose. Only the latter is relevant in assessing the argument that courts should submit to deliberate decisions by Congress or by most state legislatures. Even the most avid pro-

49. Auerbach, The Reapportionment Cases: One Person, One Vote-One Vote, One Value, 1964 SuP. CT. REv. 1, 52 (citations omitted).

50. S. Hook, The Paradoxes of Freedom 66 (1962).

51. Wright, Professor Bickel, the Scholarly Tradition, and the Supreme Court, 84 HARV. L. REv. 769, 789 (1971).

52. Id. 
ponents of an active judicial role in protecting minorities have not suggested that judicial power extends to declaring legislative inaction unconstitutional. The power of judicial review is the power to declare invalid legislation that has been enacted. But it is precisely in the opportunities that it offers for blocking legislation that the politics of pluralism offers the greatest protection to minorities.

Within the Congress, moreover, minorities are further protected by an organizational structure and procedures that permit them to exercise power beyond mere numbers to prevent enactment of legislation inconsistent with their interests. Bicameralism, the committee system, the filibuster in the Senate, the Rules Committee in the House, and a host of other familiar devices for retarding the enactment of legislation are weapons in the legislative struggle. The opportunities they provide for deflecting legislation added to the powerful moderating influence of pluralistic politics make it virtually certain that any legislation that is enacted will not be seriously inimical to the interests of minorities. Judicial review of such legislation does not, thus, serve to protect minorities from the "parade of horribles" that are generally trotted out in the course of its defense. It merely permits courts to substitute their decisions for those of Congress on issues that are likely to call for rather nice judgments about the appropriate balance between competing interests that have come into conflict. The balance struck by Congress, just because the enactment of legislation confronts so many hurdles, may fairly be understood to be supported by a broad popular consensus. It is, as I have urged throughout, difficult to understand what warrant courts can claim for setting their judgment against such a consensus.

Accepting deliberate and broadly based political decisions as authoritative may, moreover, purchase a significant gain in the legitimacy of judicial efforts to protect minorities from the most serious hazards they confront in the political process and, in doing so, contribute substantially to the effectiveness of those efforts. The most serious threats to minorities, as a survey of the United States Reports will reveal, come from governmental action that does not rest upon such decisions. The safeguards of the legislative process, as Judge Wright suggests, are generally available only to protect those groups whose numbers and organization permit them to gain the attention of Congress. Groups that cannot make visible the threat to their interests are likely to find those interests overlooked or, if noticed, given scant attention. So also, experience demonstrates that state and local governments are typically less sensitive to minority interests than the Congress. Conventional constitutional analysis unnecessar- 
ily restricts judicial power to protect minorities from these hazards. Since it regards the decisionmaking process that underlies challenged governmental action as irrelevant to the validity of that action, it treats a determination that a local ordinance, a state statute, or inadequately considered federal legislation is unconstitutional as establishing that similar legislation subsequently enacted by Congress would also be invalid, however deliberate might be the process leading to its enactment. Courts are thus led to approach the former with a deference they do not deserve. Doctrines that would permit courts to take account of differences in the decisionmaking processes leading to challenged governmental action would, thus, contribute to the courts' ability to protect minorities in those situations in which that protection is most likely to be needed. But, as suggested above, the analysis that leads to taking account of such differences also requires that courts must defer finally to deliberate decisions by broadly representative political institutions.

This brief sketch is, of course, insufficient to describe, much less to justify, a convincing alternative to more conventional theories of the judicial role in constitutional adjudication. My purpose is merely to suggest that a more modest statement of the courts' role may add significantly to its legitimacy and, moreover, that it may do so without significantly impairing the courts' ability to protect minorities. The persuasiveness of that suggestion depends, however, upon whether the several steps in the argument can survive a more complete analysis than is set out in the preceding pages.

First, the claim that constitutional law must now be understood as expressing contemporary norms regarding the distribution and limits of governmental power requires both elaboration and defense. As stated, the claim is likely to be considered extreme, as in a sense it is. Norms do not arise spontaneously; they have a history and, in the United States, that history includes the Constitution. Nevertheless, as I have argued briefly, and as I believe a more complete argument would establish even more convincingly, the evolving content of constitutional law is not controlled, nor even significantly guided, by the Constitution, understood as an historical document. The claim that constitutional law must now be understood as expressing contemporary norms is not, moreover, merely an effort to describe its current content. It rests, in part, upon an argument concerning the functions that constitutional law has come to perform in 
our system. A complete defense of the claim thus requires an identification of those functions and an analysis of their importance and of the reasons that they could not be performed if courts were limited to textual exegesis in giving content to constitutional law.

Second, there is a need to consider in much greater detail the process by which the norms to be expressed in constitutional law should be constructed. In the large, it seems fairly evident that once constitutional law is loosed from its moorings in the historical document, the norms that it expresses must be the evolving norms of the society. But, as I have urged, societal norms cannot be directly apprehended, for they do not exist independently of the process by which they are constructed. Our history establishes that courts are to have a role in the process, but what that role should be is less firmly established. Any attempt to answer that question must consider not only the limits upon the role implied by our commitment to democracy, and thus the nature of that commitment, but also the contribution that courts can make to the process by which societal values are defined and realized.

Third, the suggestion that courts ought to distinguish between governmental actions that establish societal norms and those that do not requires considerable elaboration. Two questions in particular call for further attention. First, in light of our tradition of federalism, what weight should be given to the decisions of a state legislature? I have suggested that the decisions of one or a few state legislatures ought not to be understood as establishing societal norms but that perhaps the concurrence of many should be. Defending that position requires an examination of the contemporary condition of federalism in the United States. Second, the suggestion that courts ought to distinguish between those acts of Congress that do and do not represent deliberate decisions fails to indicate how courts are to make that determination. Although I believe that they can do so, and that constitutional decisions are in fact often influenced by judicial perceptions of the deliberateness of congressional judgments, the argument remains to be made.

Fourth, many students of constitutional law believe that the ability of courts, and especially of the Supreme Court, to perform the functions that our history has thrust upon them depends upon a popular understanding that courts are the ultimate expositors of the meaning of the Constitution. It is a fair question whether courts can maintain the role that my argument assigns them if it is generally understood that their decisions do not rest upon the Constitution and that they may be overturned by the ordinary processes of legislation. 
Finally, a full defense of the thesis I have sketched requires assessment of the extent to which its acceptance would alter the existing content of constitutional law. In the large, constitutional law is an important repository of our national experience. A theory that calls for massive repudiation of that experience is not likely to be heeded, nor should it be. The object of a theory of judicial review is, or should be, to achieve substantial consonance between the body of decisions that compose constitutional law and generally accepted principles governing the distribution of governmental authority. Of course, no theory is likely to achieve complete harmony. But a theory that is consistent with those principles and that accounts for most decisions, especially those that are most confidently thought to be correct, may point the way to a more satisfactory definition of the courts' role in cases in which that role is in doubt. ${ }^{\overline{3}}$

Conventional theories of judicial review fail the test stated in the preceding paragraph. They either do not explain the evolving content of constitutional law, or they cannot be reconciled with principles that define the nation's commitment to democracy. Whether the theory that I have advanced is more satisfactory is a question that can be answered only after a more detailed description of it than that offered in this essay.

53. Cf. J. Rawls, supra note 14 , at $46-53$. 